\title{
Phytochemical screening and effect of ethanol root extract of Microdesmis puberula on some haematological and biochemical parameters in normal male albino Wistar rats
}

\author{
Akpanyung, Edet Okon ${ }^{1 *}$, Ita, Sunday Otu ${ }^{2}$, Opara, Kiki Adaeze ${ }^{1}$, Davies, Koofreh Godwin ${ }^{2}$, \\ Ndem, Jessie Idongesit ${ }^{1}$ and Uwah, Anthony Fidelis ${ }^{1}$ \\ ${ }^{1}$ Department of Biochemistry, University of Uyo, Uyo, Akwa Ibom State, Nigeria. \\ ${ }^{2}$ Department of Physiology, University of Uyo, Uyo, Akwa Ibom State, Nigeria.
}

Accepted 25 July, 2013

\begin{abstract}
Microdesmis puberula Hook f. ex. Planch (Pandaceae) is one of the understudied medicinal plants whose pharmacological properties are beginning to be elucidated. In the present study, ethanol root extract of $M$. puberula was used to assess its effects on some biochemical and haematological parameters in male rats. The root extract was administered in graded doses of 200,400 and $600 \mathrm{mg} / \mathrm{kg}$ body weight to groups II, III and IV, respectively while the control group received $1 \mathrm{mI}$ of Tween 80 solution. Phytochemical screening of the extract revealed the presence of saponins, cardiac glycosides, deoxysugars, alkaloids and terpenes. The results of acute toxicity study showed that the extract has a wide margin of safety. The extract did not exhibit any significant effect $(p>0.05)$ on haematological parameters such as packed cell volume (PCV), haemoglobin ( $\mathrm{Hb})$, mean corpuscular volume (MCV), mean corpuscular haemoglobin concentration (MCHC) and red blood cell (RBC) count. Alanine aminotransferase (ALT) and aspartate aminotransferase did not show any significant difference $(p>0.05)$ between control and treatment groups. There was a significant $(p<0.05)$ increase in serum cholesterol, low density lipoprotein-cholesterol (LDL-C), triacylglycerols (TGs) and significant $(p<0.05)$ decrease in high density lipoprotein-cholesterol (HDL-C) as a consequence of the administration of this extract. Generally, the results indicate that there were no serious adverse effects associated with the use of this extract except in the case of lipid profile studies.
\end{abstract}

Key words: Microdesmis puberula, ethanol extract, phytochemicals, haematological/biochemical parameters, toxicity.

\section{INTRODUCTION}

Microdesmis puberula Hook. F. ex Planch (Pandaceae) is a dioecious plant that can grow up to a height of about 6 $\mathrm{m}$ if not harvested or prematurely cut (Dounias, 2008). It occurs predominantly from Eastern Nigeria down to DR Congo and Uganda. In Nigeria, its local names include Mkpiri or Mbugbo in Igbo; Idi-apata in Yoruba and Ntabit in Ibibio language (Esonu et al., 2004).

It has been reported that various parts of $M$. puberula (stem bark, leaves and roots) are used for several medicinal purposes (Dounias, 2008; Okany et al., 2012). In Eastern Nigeria, the roots of this plant are used in the treatment of gonorrhoea and erectile dysfunction (Ajibesin et al., 2008; Zamblé et al., 2006; Roumy et al., 2008). The analgesic and antistress properties of $M$. puberula have recently been reported (Okany et al., 2012). Several polyamine derivatives were earlier identified 
in the hydromethanolic root extract of this plant (Roumy et al., 2008; Zamblé et al., 2006).

Despite the reported uses of $M$. puberula in traditional medicine, there are no reported studies addressing the issue of safety in the administration of this plant extract. Therefore, the present study was designed to evaluate the effect of the root extract on some hepatic, renal and haematological parameters in normal rats.

\section{MATERIALS AND METHODS}

\section{Plant}

Samples of $M$. puberula were uprooted from the bushes around the University of Uyo main campus, and were authenticated at the Department of Botany of the same university. A voucher specimen $(31 \mathrm{~L})$ was deposited at the departmental herbarium.

\section{Preparation of root extract}

The roots were washed, air-dried for two weeks and ground into a powder using a mechanical grinder. About $200 \mathrm{~g}$ of the powdered sample were soaked in $500 \mathrm{ml}$ of $80 \%$ ethanol in a conical flask and were covered with aluminium foil. The mixture was stirred intermittently and allowed to stand for a period of $48 \mathrm{~h}$. The resulting decoction was filtered and the filtrate was subjected to complete solvent evaporation using a regulated hot plate at a temperature of 40 to $50^{\circ} \mathrm{C}$. The extract obtained was packaged in an air tight container and was stored below $4^{\circ} \mathrm{C}$ until required.

\section{Phytochemical screening}

Phytochemical screening of the extract was carried out using standard procedures as described by Sofowora (1993) and Trease and Evans (2002).

\section{Determination of median lethal dose $\left(\mathrm{LD}_{50}\right)$}

The $L_{50}$ of the root extract was determined by the method of Lorke (1983). Twelve albino mice with average weight of $25.3 \mathrm{~g}$ were used. In the first phase, nine mice were divided into three groups of three animals per group and were respectively treated with the extract at doses of 100,500 and $1000 \mathrm{mg} / \mathrm{kg}$ body weight orally. They were observed for signs of toxicity within $24 \mathrm{~h}$ period. In the second phase of the experiment, three mice were divided into three groups of one mouse each and were treated with the extract at doses of 1600,2900 and $5000 \mathrm{mg} / \mathrm{kg}$ body weight orally. The $L_{50}$ was calculated as the geometric mean of the maximum dose with $0 \%$ mortality and the minimum dose producing $100 \%$ mortality.

$L D_{50}=\sqrt{ } D_{0} \times D_{100}$

where $D_{0}$ is the maximum dose producing $0 \%$ mortality and $D_{100}$ is the minimum dose producing $100 \%$ mortality.

\section{Experimental animals}

Male albino rats (210 to $220 \mathrm{~g}$ ) were obtained from the animal house facility of the Faculty of Basic Medical Sciences, University of Uyo, Uyo. The animals were housed in a well ventilated experimental section of the animal house and maintained under standard conditions of $12 \mathrm{~h}$ light and dark cycle with room temperature at $25 \pm 3^{\circ} \mathrm{C}$ and 33 to $60 \%$ humidity. The animals were maintained on standard pellet diet (Pfizer Livestock Company Ltd, Aba, Nigeria) and allowed to acclimatize for a period of two weeks after which they were divided into four groups of six rats per group. Group I served as control whereas groups II, III and IV received oral doses of 200,400 and $600 \mathrm{mg} / \mathrm{kg}$ body weight of the extract, respectively.

Administration of the extract was carried out between the hours of 10 am and 12 noon daily. The experiment lasted 14 days.

\section{Sample collection}

The animals were anaesthetized with chloroform vapour $24 \mathrm{~h}$ after the last administration of the extract. Blood samples were collected by cardiac puncture using sterile syringes and needles. The blood samples were divided into two portions. One portion (about $2 \mathrm{ml}$ ) was transferred into sample bottles containing ethylenediaminetetraacetic acid (EDTA) as anticoagulant and used for the assessment of haematological parameters. The other portion of blood was collected in sterile plain tubes without anticoagulant and allowed to clot. Serum was obtained by centrifugation at $3000 \mathrm{~g}$ for 5 min using a bench top centrifuge (MSE Minor, England). The serum samples were stored frozen until required for analyses.

\section{Determination of haematological parameters}

Haematological parameters were determined within $2 \mathrm{~h}$ of sample collection using Mindary ${ }^{\text {TM }}$ Differential BC 5300 Automated Hematologic Analyser at the Haematology Unit of the University of Uyo Teaching Hospital.

\section{Determination of serum enzymes}

The serum enzymes, alanine aminotransferase (ALT) and aspartate aminotransferase (AST) were carried out using the RANDOX kit (Randox Laboratories Ltd, England).

\section{Determination of lipid profile}

Estimation of total serum cholesterol was carried out using the cholesterol oxidase-phenol-aminophenazone (CHOD-PAP) method and high density lipoprotein-cholesterol (HDL-C) by polyethylene glycol cholesterol oxidase-phenol-aminophenazone (PEG-CHODPAP) method using reagent kits supplied by Randox Laboratories, England.

Triacylglycerols (TGs) were determined using glycerol phosphate oxidase-phenol aminophenazone (GPO-PAP end point assay) method using diagnostic reagent kit (Randox Laboratories, England). LDL-cholesterol was calculated from the equation:

Serum LDL-cholesterol $(\mathrm{mg} / \mathrm{dl})=$ Total cholesterol $-(\mathrm{HDL}+\mathrm{TG} / 5)$

\section{Estimation of blood urea nitrogen (BUN) and creatinine}

These were determined using reagent kits supplied by Randox Laboratories Ltd, England.

\section{Statistical analysis}

Data obtained were expressed as means \pm standard deviation (SD). Statistical analysis was carried out using the one way analysis of 
Table 1. Phytochemical profile of ethanolic root extract of $M$. puberula.

\begin{tabular}{lc}
\hline Constituent & Inference \\
\hline Tannins & - \\
Phlobatannins & - \\
Saponins & + \\
Flavonoids & - \\
Anthraquinones & - \\
Cardiac glycoside & ++ \\
Deoxy sugar & ++ \\
Terpenes & + \\
Alkaloids & + \\
\hline -= Absent; + = present; $++=$ highly present.
\end{tabular}

Table 2. Effect of the ethanolic root extract of M. puberula on haematological indices in normal male Wistar rats.

\begin{tabular}{lccccccc}
\hline Group & RBC $\left(\times 10^{6} \boldsymbol{\mu l}\right)$ & PCV $(\%)$ & Hb (g/dl) & MCV (fl) & MCH $(\mathbf{p g})$ & MCHC $(\mathbf{g} / \mathbf{d l})$ & WBC $\left(\times 10^{3} \boldsymbol{\mu l}\right)$ \\
\hline I (control) & $8.64 \pm 0.09$ & $40.70 \pm 2.68$ & $14.45 \pm 0.14$ & $52.15 \pm 0.63$ & $16.73 \pm 0.18$ & $32.10 \pm 0.10$ & $8.25 \pm 0.65$ \\
II $(200 \mathrm{mg} / \mathrm{kg})$ & $7.87 \pm 0.30$ & $40.80 \pm 0.26$ & $14.34 \pm 0.28$ & $54.38 \pm 0.37$ & $17.68 \pm 0.11$ & $32.53 \pm 0.19$ & $11.17 \pm 0.80^{\mathrm{a}}$ \\
III $(400 \mathrm{mg} / \mathrm{kg})$ & $8.17 \pm 0.23$ & $41.55 \pm 1.78$ & $14.42 \pm 0.15$ & $52.77 \pm 0.60$ & $17.27 \pm 0.19$ & $32.68 \pm 0.31$ & $18.40 \pm 0.46^{\mathrm{a}, \mathrm{b}}$ \\
IV $(600 \mathrm{mg} / \mathrm{kg})$ & $8.15 \pm 0.21$ & $41.20 \pm 2.88$ & $14.07 \pm 0.13$ & $53.58 \pm 0.80$ & $17.30 \pm 0.38$ & $32.18 \pm 0.33$ & $15.00 \pm 0.52^{\mathrm{a}, \mathrm{b}, \mathrm{c}}$ \\
\hline
\end{tabular}

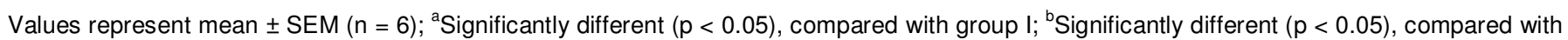
group II; 'Significantly different $(p<0.05)$, compared with group III.

variance (ANOVA). Turkey's multiple range tests was used to determine the significance of difference between means. Statistical significance was accepted at $p<0.05$.

\section{RESULTS AND DISCUSSION}

The phytochemical screening of the ethanolic root extract of $M$. puberula (Table 1) revealed the presence of trace or moderate amounts of saponins, cardiac glycosides, deoxy sugars, terpenes and alkaloids. Okany et al. (2012) has also reported the presence of flavonoids, saponins and cardiac glycosides in the methanolic stem wood extract of the plant. Alkaloids constitute a diverse group of secondary metabolites in plants with pharmacologic activities (Roberts and Wink, 1998). The cardiac glycosides increase the force of contraction of the heart and are valuable in the treatment of heart failure (Stryer, 1995). Terpenes are important as components of essential oils e.g. menthol (Holme, 2004). Deoxy sugars are components of several bioactive compounds (Kennedy and White, 1983). Saponins have the properties of protein precipitation, cholesterol binding and haemolysis of red blood cells (Sofowora, 1993).

The $L_{50}$ of the extract was found to be higher than $5000 \mathrm{mg} / \mathrm{kg}$ body weight orally. Evaluation of $\mathrm{LD}_{50}$ has been described as an important step in the toxicological investigation of an unknown substance (Lorke, 1983). The classification of acute systemic toxicity based on $\mathrm{LD}_{50}$ values as recommended by the Organization for
Economic Cooperation and Development (OECD) is as follows: very toxic, $\leq 5 \mathrm{mg} / \mathrm{kg}$; toxic $>5 \leq 50 \mathrm{mg} / \mathrm{kg}$; harmful, $>50 \leq 500 \mathrm{mg} / \mathrm{kg}$; no label, $>500 \leq 2000 \mathrm{mg} / \mathrm{kg}$ (Walum, 1998). Lorke (1983) noted that $L_{50}$ values greater than $5000 \mathrm{mg} / \mathrm{kg}$ are of no practical interest. Hence, the $L_{50}$ value obtained in the present study shows that the extract is non toxic when administered via oral route. It is therefore considered safe for use by humans. Okany et al. (2012) had also observed that the stem wood extract of this plant has a wide margin of safety when administered orally. Similarly, Zamblé et al. (2007) reported that the aqueous root extract of Microdesmis keayana, a closely related species to $M$. peberula, did not cause any mortality or changes in behaviour at a dose of $2000 \mathrm{mg} / \mathrm{kg}$ body weight.

Table 2 shows the effects of the extract on haematological parameters. There was a marginal dose dependent increase in packed cell volume (PCV) which was not significantly different from control. Similarly, the results for red blood cell (RBC), haemoglobin $(\mathrm{Hb})$, mean corpuscular volume (MCV), mean corpuscular haemoglobin (MCH), and mean corpuscular haemoglobin concentration $(\mathrm{MCHC})$ were found not to be significantly different from the control. This indicates that the extract does not possess any haematoxic effect. An important condition for safety in the administration of medicinal plants is the need for such plant extracts to maintain normal haematological state in animals or to reverse any existing negative haematological status (Uboh et al., 
Table 3. Effect of the ethanolic root extract of M. puberula on ALT, AST, total protein and albumin levels in normal male Wistar rats.

\begin{tabular}{lcccc}
\hline Group & ALT (U/L) & AST (U/L) & Total protein (g/dl) & Serum albumin (g/dl) \\
\hline I (control) & $18.69 \pm 1.56$ & $33.11 \pm 2.07$ & $58.11 \pm 4.30$ & $24.08 \pm 2.69$ \\
II $(200 \mathrm{mg} / \mathrm{kg})$ & $18.23 \pm 2.30$ & $33.46 \pm 3.22$ & $56.98 \pm 4.32$ & $23.88 \pm 2.56$ \\
III $(400 \mathrm{mg} / \mathrm{kg})$ & $18.75 \pm 3.96$ & $33.68 \pm 3.98$ & $57.66 \pm 4.89$ & $23.98 \pm 2.63$ \\
IV $(600 \mathrm{mg} / \mathrm{kg})$ & $18.75 \pm 4.42$ & $34.33 \pm 2.01$ & $58.14 \pm 4.24$ & $25.86 \pm 2.52$ \\
\hline
\end{tabular}

Values represent mean $\pm \operatorname{SEM}(n=6) ; p>0.05$ in all treatment groups.

2010).

There was a significant $(p<0.05)$ increase in WBC count across all treatment groups. Such increase has been attributed to various factors such as infection and inflammatory response (Teguia et al., 2007). Other factors which have been implicated include excitement, fear, pain or apprehension in animals in the course of the experiment (Mbaya et al., 2008). However, lgwe et al. (2011) surmised that increase in WBC count is a normal immune response to assault on the animal system by drug administration.

The results obtained for the effect of the extract on serum enzymes, total protein and albumin levels in the rat are shown in Table 3. There was no significant change in the activities of serum enzymes assayed. The values obtained for total protein and albumin compared favourably with the control.

ALT and AST play important roles in diagnostic enzymology (Naik, 2010). ALT is widely accepted as a more specific marker of hepatocellular damage, because it occurs in the cytosol whereas AST has cytosolic and mitochondrial forms and is present in various tissues including the heart, skeletal muscle, kidneys, brain, pancreas and blood cells (Batzakis and Briere, 1979). The aminotransferase enzymes leak into circulation when liver cells or their membranes are damaged. Consequently, the estimation of their activities in serum serves as a useful quantitative marker of hepatic injury (Giboney, 2005). In view of the fact that the root extract did not produce any significant changes in serum enzyme activities, it can be inferred that the extract did not inflict hepatocellular injury on the experimental animals (Kew, 2000).

Plasma proteins are synthesized in the liver and the synthetic functions of the liver is compromised in hepatocellular damage. Hence, determination of serum protein including albumin is one method of assessing liver function. In the present study, there was no significant alteration in serum total protein and albumin. Hence, the synthetic function of the liver is preserved during the administration of the extract.

The effect of the extract on BUN and creatinine is presented in Table 4. Estimation of BUN and creatinine are screening tests for renal function. These metabolites are usually eliminated from the body through glomerular filtration. An increased plasma creatinine and urea imply
Table 4. Effect of the ethanolic root extract of $M$. puberula on serum creatinine and BUN in normal male Wistar rats.

\begin{tabular}{lcc}
\hline Group & Serum creatinine (mg/dl) & BUN (mg/dl) \\
\hline I (control) & $1.80 \pm 0.46$ & $22.60 \pm 4.39$ \\
II $(200 \mathrm{mg} / \mathrm{kg})$ & $1.62 \pm 0.33$ & $20.59 \pm 2.55$ \\
III $(400 \mathrm{mg} / \mathrm{kg})$ & $1.30 \pm 0.11$ & $17.26 \pm 3.49$ \\
IV $(600 \mathrm{mg} / \mathrm{kg})$ & $1.18 \pm 0.51$ & $18.61 \pm 5.30$ \\
\hline
\end{tabular}

Results presented as mean $\pm \operatorname{SEM}(n=6) ; p>0.05$ in all treatment groups.

the impairment of renal function. The serum level of these metabolites is usually parallel to the severity of renal malfunction. The present study did not demonstrate any significant alterations in BUN and creatinine and this suggests the absence of nephrotoxicity as a consequence of the administration of the extract.

In lipid profile studies, the parameters of interest include serum cholesterol, TGs, low density lipoprotein cholesterol (LDL-C) and HDL-C. Alterations in these lipid fractions provide useful information concerning the status of lipid metabolism as well as predisposition to atherosclerosis and its associated coronary disease (Singh et al., 2012).

The effects of the ethanolic root extract of $M$. puberula on lipid profile are shown in Table 5. Serum cholesterol, LDL-C and TGs were found to increase significantly $(p<$ 0.05 ) in a dose-dependent fashion as compared to the control. Increase in serum cholesterol could be attributed to an enhanced $\beta$-oxidation resulting in increased levels of acetyl coenzyme $A(\mathrm{CoA})$, a key substrate in the biosynthesis of the cholesterol (Naik, 2010). High blood cholesterol is an important risk factor for cardiovascular disease (Treasure et al., 1995). Consequently, the observed increase in serum cholesterol is detrimental to the health of the animals.

TGs are the major storage forms of fatty acids. Increase in serum concentrations of TGs as observed in the present study could be attributed to increased lipolysis which may ultimately deplete the body store of fatty acids. It has been reported that patients with cardiovascular disease exhibit high serum levels of TGs (Singh et al., 2012). Hence, the result of the present study calls for caution in the administration of the root 
Table 5. Effect of the ethanolic root extract of M. puberula on serum lipid profile of male Wistar rats.

\begin{tabular}{lcccc}
\hline Group & Total cholesterol (mg/dl) & HDL-C (mg/dl) & LDL-C (mg/dl) & Triglycerides (mg/dl) \\
\hline I (control) & $76.68 \pm 2.74$ & $57.46 \pm 2.92$ & $15.50 \pm 0.22$ & $104.36 \pm 2.18$ \\
II (200 mg/kg) & $83.66 \pm 1.94^{\mathrm{a}}$ & $45.35 \pm 2.55^{\mathrm{a}}$ & $30.88 \pm 1.54^{\mathrm{a}}$ & $113.87 \pm 2.39^{\mathrm{a}}$ \\
III $(400 \mathrm{mg} / \mathrm{kg})$ & $87.48 \pm 3.20^{\mathrm{a}}$ & $41.21 \pm 1.80^{\mathrm{a}}$ & $42.00 \pm 2.80^{\mathrm{a}}$ & $113.78 \pm 2.46^{\mathrm{a}}$ \\
IV $(600 \mathrm{mg} / \mathrm{kg})$ & $112.93 \pm 2.40^{\mathrm{a}}$ & $39.31 \pm 1.72^{\mathrm{a}}$ & $51.94 \pm 3.93^{\mathrm{a}}$ & $127.82 \pm 2.68^{\mathrm{a}}$ \\
\hline
\end{tabular}

Values represent mean \pm SEM $(n=6)$. ${ }^{a}$ Significantly different $(p<0.05)$ from control.

extract of M. puberula. The present study has also shown that serum levels of HDL-C decreased significantly $(p<$ 0.05 ) in a dose-dependent fashion at the end of experimental period.

The results of the present study has shown that administration of ethanol root extract of $M$. puberula does not have any significant toxic effect on liver and kidney functions as well as on haematological parameters in male rats. The observed alterations in serum lipid profile could predispose the animals to atherosclerosis, hence the need for caution in the use of this plant root extract for medicinal purposes.

\section{REFERENCES}

Ajibesin KK, Ekpo BA, Bola DN, Essien EE, Adesanya SA (2008). Ethnobotanical survey of Akwa lbom State of Nigeria. J. Ethnopharmacol. 115:387-488.

Batzakis KG, Briere RO (1979). Interpretative Enzymology. Thomas Nelson. Springfield. Illinois, pp. 225-242.

Dounias E (2008). Microdesmis puberula Hook. F. ex Planch. In: Plant resources of Tropical Africa Medicinal Plants1. Schmeizer GH and Gurib-Fakim A (eds). Prota Foundation. Wageningen, Netherlands, 11(1):382-384.

Esonu BO, Azubuike, JC, Ukwu HO (2004). Evaluation of M. puberula leaf meal as feed ingredient in laying hen diets. Int. J. Poult. Sci. 3(2):96-99.

Giboney PT (2005). Mildly elevated liver transaminase in the asymptomatic patient. Am. Fam. Phys. 76(6):1105-1110.

Holme TA (2004). Terpenes: Chemistry, Foundations and Applications. http://www.encyclopedia.com- Accessed $24^{\text {th }}$ April 2013.

Igwe CU, Onwuliri VA, Osuagwu CG, Onyeze GOC, Ojiako OA (2011). Biochemical and haematological studies on ethanol leaf extract of Spondias mombin Linn. Biochem. Anal. Biochem. 1(1):1-5.

Kennedy JP, White CA (1983). Bioactive Carbohydrates in Chemistry, Biochemistry and Biology. Ellis Horwood publishers, UK, pp 130-155.

Kew MC (2000). Serum aminotransferase concentration as evidence of hepatocellular damage. Lancet 355(9204):591-592.

Lorke D (1983). A new approach to practical acute toxicity testing. Arch. Toxicol. 53:275-289.

Mbaya AW, Aliyu MM, Nwosu CO, Egbe-Nwiyi TNC, Kumshe HA (2008). Studies on the leucocytic response to experimental infection with Trypanosoma brucei and Haemonchus contortusin red fronted gazelles. Sahel J. Vet. Sci. 7:37-45.

Naik P (2010). Biochemistry $\left(3^{\text {rd }}\right.$ edn). Jay pee Publishers. New Delhi 341:564-565.
Okany CC, Ishola IO, Ashorobi RB (2012). Evaluation of analgesic and antistress potential of methanolic stem wood extract of $M$. puberula Hook .f. ex. Planch (Pandaceae) in mice. Int. J. Appl. Res. Nat. Prod. 5(3):30-36.

Roberts MF, Wink M (1998). Alkaloids: Biochemistry, Ecology and Medicinal Applications. Plenum Press. New York, pp 1-8.

Roumy V, Hermebelle T, Zamble A, Quare S, Sahpaz S, Bailleul F (2008). Characterization and identification of spermine and spermidine derivatives in Microdesmis. keayana and Microdesmis. Puberula roots by lonisation Tandem Mass Spectrometry and HighPerformance Liquid Chromatography/Electrospray Ionisation Tandem Mass Spectrometry. Eur. J. Mass Spectromet. 14(2):111-115.

Singh R, Singh S, Singh SP, Jain IP, Sing S (2012). Study of alterations in serum lipids by cardioselective beta blockers in Albino rats. Asian J. Pharm. Life Sci. 2(2):116-123.

Sofowora A (1993). Medicinal Plants and Traditional Medicine in Africa $\left(2^{\text {nd }}\right.$ ed). Spectrum Books Ltd. Ibadan, pp 255-256.

Stryer L (1995). Biochemistry. W H Freeeman and Company. New York, pp. 313- 314.

Teguia A, Telefo PB, Fotso RG (2007). Growth performance, organ development and blood parameters of rats fed graded levels of steeped and cooked taro tuber (Colocasia esculenta var esculenta) meal. Livest. Resourc. Rural Dev. 19:1-8.

Trease GE, Evans WC (2002). Pharmacognosy ( $13^{\text {th }}$ edn). Bailliere Tindall, London, pp. 214-393.

Treasure CB, Klein JL, Wein-trauut WS, Talley JD, Stillabow MS, Kisonski AS, Zhang J, Boccuzzi SJ, Codarholm JC, Alexandar RW (1995). Beneficial effect of cholesterol lowering therapy on the coronary endothelium in patients with CHD. N. Engl. J. Med. 332:481-486

Uboh FE, Okon IE, Ekong MB (2010). Effect of aqueous Extract of Psidium guajava leaves on liver enzymes histological integrity and haematological indices in rats. Gastroenterol. Res. 3(1):32-38.

Walum E (1998). Acute oral toxicity. Environ. Health Perspect. 106:497503

Zamblé A, Yao D, Martin-Nizard F, Sahpez S, Offoumou M, Duriez P, Brunet C, Bailleul $F$ (2006). Vasoactivity and antioxidant properties of M. keayana roots. J. Ethnopharmacol. 104:263-269.

Zamblé A,Sapha JS, Brunet C, Bailleul F (2007). Effects of $M$ keayana roots on sexual behaviour of male rats. Phytomedicine 15(8):625 629. 